\title{
Deep Breathing Relaxation Techniques Improve Emotional Control on Tuberculosis Patients
}

\author{
Domianus Namuwali $^{1}$, Fery Agusman Motuho Mendrofa ${ }^{2}$, Meidiana Dwidiyanti ${ }^{3}$ \\ ${ }_{1,3}$ Master Student of Nursing at Diponegoro University, Indonesia \\ ${ }^{2}$ Department of Nursing Sciences, Karya Husada Institute of Health Science, Indonesia
}

\begin{tabular}{l}
\hline Article Info \\
\hline Article history: \\
Received Jun 17, 2016 \\
Revised Aug 13, 2016 \\
Accepted Aug 20, 2016 \\
\hline
\end{tabular}

Keyword:

Emotional Control

Patient

Relaxation

Tuberculosis

\begin{abstract}
Tuberculosis is an infectious disease caused by Tuberculosis Mycobacterium. Based on WHO report in 2014, the world population suffering from tuberculosis were 9.6 million people while in Indonesia it was amounted 324 539 people. Tuberculosis patients have a tendency to experience emotional disturbance due to the illness. A deep breathing relaxation is a nursing action for controlling emotions of tuberculosis patients. The study design is quasiexperimental design with one group pre-test-post-test. Data were collected by using a questionnaire adapted from Gross and John (2003). Data were analyzed using paired $t$ test. The results of this research is deep breathing relaxation technique is effective to control emotions of tuberculosis patients with $\mathrm{p}$ value $=0,001$.
\end{abstract}

Copyright $\odot 2016$ Institute of Advanced Engineering and Science. All rights reserved.

\section{Corresponding Author:}

Domianus Namuwali, Master Student of Nursing, Diponegoro University, Jalan Adam Malik No 126, Waingapu, Sumba Timur, Nusa Tenggara Timur, Indonesia. Email : domianus2012@gmail.com

\section{INTRODUCTION}

Based on the WHO report in 2014 it was estimated that there were 9.6 million people worldwide who suffered from tuberculosis. Indonesia ranks third as the most populous country suffer tuberculosis by the number of tuberculosis in 2014, that was 324 539[1]. Patients with tuberculosis have a tendency to experience emotional disturbances. Results of research conducted by Paulo B.X \& Bruno P states that $44.4 \%$ of tuberculosis patients experiencing emotional distress [2].

Patients who are undergoing treatment are necessary to get emotional control in order not to aggravate the patient's condition. Emotional control is an attempt to hide and to calm the emotions of expressing negative emotions such as anger, depression and anxiety. Control emotions affect the adjustment of disease through adaptive processes by using strategies of coping with stress [3].

A nurse is one of the team that provides health care in patients with tuberculosis that has a central role to provide emotional support for patients during illness and treatment [4]. One of the treatments to reduce emotional disorders in patients with tuberculosis is deep breathing relaxation. Relaxation that is performed for 5 to 10 minutes can improve blood flow throughout the body so that the body becomes more relaxed, and in the end it can relieve pain and mental stress in patients [5].

\section{RESEARCH METHOD}

The method used in this research was quasi-experimental. The study design was one group for pretest and posttest without a control group. The population in this study was all patients with pulmonary tuberculosis in Public Health Center (BKPM). There were 31 samples in this study. Inclusion criteria in this 
study as follows: tuberculosis patients that were registered in Magelang BKPM, Patients under early and advanced stages of treatment, aged 15-60 years old, patients who do not experience mental illness, able to read and write and willing to be investigated. Exclusion criteria were patients with shortness of breath, extra pulmonary tuberculosis, complications of HIV/AIDS and diabetes mellitus.

Sampling was conducted by purposive sampling, the sample that is based on the intention and purpose as determined by researcher. The data collection was conducted using questionnaires adopted from Gross and John, which consists of 10 questions. Results of validity and reliability tests towards this questionnaire showed that only seven questions valid for the research, therefore, this study only used valid and reliable questionnaire. Pre test data was collected in the first week and then the respondents were trained in breath relaxation techniques at the first, the second and third weeks. Post test was conducted at the third week. Data analysis was performed using paired t test if the data normally distributed, but if it is not then it will be tested with Wilcoxon test [6].

\section{RESULTS AND ANALYSIS}

Characteristics of respondents presented in Table 1. The characteristics included gender, age, education, and occupation. In Table 1 it is known that most male respondents 18 (58.1\%); the largest age group is the 26-45 years old, 15 (48.4\%); most education of respondents is High School 17 (54.8\%); and most respondents were private employees that was 9 (29\%).

Table 1. Characteristics of Respondents

\begin{tabular}{|c|c|c|}
\hline Characteristics of respondents & Frequency & Percent \\
\hline \multicolumn{3}{|l|}{ Gender } \\
\hline a. Male & 18 & 58.1 \\
\hline b. Famale & 13 & 41.9 \\
\hline \multicolumn{3}{|l|}{ Age } \\
\hline a. $15-25$ years old & 8 & 25.8 \\
\hline $26-45$ years old & 15 & 48.4 \\
\hline $47-60$ years old & 8 & 25.8 \\
\hline \multicolumn{3}{|l|}{ Education } \\
\hline a. Elementary School & 5 & 16.1 \\
\hline Junior High School & 9 & 29.0 \\
\hline c. High school & 17 & 54.8 \\
\hline \multicolumn{3}{|l|}{ Occupation } \\
\hline a. Private employees & 9 & 29.0 \\
\hline Entrepreneur & 5 & 16.1 \\
\hline Labor & 4 & 12.9 \\
\hline Housewife & 3 & 9.7 \\
\hline Student & 4 & 12.9 \\
\hline f. Etc. & 2 & 6.5 \\
\hline g. Does not work & 4 & 12.9 \\
\hline
\end{tabular}

Sources: Primary data, in 2016.

\subsection{Normality data test}

In Table 2, the result of Shapiro-Wilk normality test shows significance values for the pre-test and posttest is $>0.05$. Thus, it can be concluded that the group of pre-test and post test data was normally distributed so that the analysis of the data used the paired t test.

Table 2. Test of Data Normality

\begin{tabular}{lcccccc}
\hline & \multicolumn{3}{c}{ Kests of Normality $^{\text {Kolmogorov-Smirnov }}$} & \multicolumn{3}{c}{ Shapiro-Wilk } \\
& Statistic & df & Sig. & Statistic & Df & Sig. \\
\hline pretest & .175 & 31 & .017 & .941 & 31 & .087 \\
posttest & .075 & 31 & $.200^{*}$ & .979 & 31 & .787 \\
\hline
\end{tabular}

*. This is a lower bound of the true significance.

a. Lilliefors Significance Correction 


\subsection{Emotion control}

Table 3 presents the result of bivariate test. In Table 3 it is known that there are significantly differences in the average (mean) before and after relaxation, with the value of CI 95\% between 5.65 to 10.28 .

Table 3. Comparison of Mean and Standard Deviation Before and After the Deep Breath Relaxation

\begin{tabular}{cccccccc}
\hline Emotion control & $\mathrm{n}$ & Mean & SD & \multicolumn{2}{c}{ Difference } & \multirow{2}{*}{ CI 95\% } & \multirow{2}{*}{$\mathrm{P}$} \\
\hline Before & 31 & 30.03 & 5.73 & 7.97 & 7.08 & \multirow{2}{*}{$5.65-10.28$} & \multirow{2}{*}{0.001} \\
After & 31 & 38.00 & 6.05 & & & \\
\hline
\end{tabular}

\section{DISCUSSION}

In this study researchers wanted to examine the effect of relaxation techniques to control emotions of patients with tuberculosis. The results in Table 2 confirmed that the value of mean and standard deviation was $30.03( \pm 5.72)$ before the treatment of deep breathing relaxation techniques, and after the treatment the mean and standard deviation was $38.00( \pm 6.05)$ with $p$ value $=0.001$. The results of this study indicated that deep breathing relaxation techniques significantly effected on controlling emotions of patients with tuberculosis.

This results is supported by the research results conducted by Yilmaz, GS et al (2015) in patients with breast cancer which mentioned that before the intervention group having relaxation exercises, the mean and standard deviation was $42.26( \pm 7.49)$ and after the exercises was $36.20( \pm 7.49)$, with p-value $=001$ [7]. The results are also similar to the study conducted by M.J. Naveen [5] towards patients with Chronic Obstructive Pulmonary Disease (COPD). It was stated that the pretest results against intervention group was $14(70 \%)$ from the patients who had severe anxiety and $6(30 \%)$ from patients who had moderate anxiety. In posttest, afterward, there were only found $2(10 \%)$ patients with mild anxiety and $18(90 \%)$ patients with moderate anxiety [5].

The other similar study was performed by Lin MF et al (2010) towards the undergoing chemotherapy patients with cancer. The study found that before verbal relaxation to the intervention group, the anxiety level reached the mean and standard deviation of 41.07 (13.71) and after verbal relaxation the anxiety level obtained the mean and standard deviation of 31.63 (10.96), with p value 0,001 [8]. This study was also related to the study of Sepasi, $\mathrm{N}$ et al [9]. to breast cancer patients. It was stated that the value of mean and standard deviation towards intervention group of relaxation exercises of their emotional well-being pre-test was 9.90 (3.68) and in the post test it obtained 19.40 (2:41) with $\mathrm{P}$ value <0.001 [9].

Emotion is a situation that is volatile in the individual that serves as an inner adjustment (adjustment from inside) to the environment to achieve well-being and safety of patients [10]. The psychological impact on tuberculosis patients is depressed, disappointed, angry and anxious. The research conducted by Martin. L.R et al [11] indicated that one of the strongest factors caused non-adherent patients on taking tuberculosis medication is depressed. Depressed patients have non-compliance medication risks by $27 \%$. According to Martin et al [11].patients with tuberculosis will experience cognitive impairment, pessimistic and withdraw from social environment that causes reducing ability to follow treatment regimens.

Emotional control is the tendency to hide and calm the emotions of negative emotions, such as anger, depression or anxiety. Controlling emotions influence the adjustment to living with the disease through much more complex adaptive processes such as strategies for coping with stress [3].

The high capability of controlling emotions was found in female because they are better in keeping interpersonal relations [12]. The ability to control emotions remained stable in adults because at the adult ages the attention and memory aimed at a positive effect by processing a negative stimulus into a positive stimulus [13]. It can be argued that the more age, the more stable the emotional ability. Mahmud in Sobur [10] mentioned some rules for controlling emotions, they are: Deal with the emotions of people, reinterpreted the situation, develop a sense of humor and a realistic attitude. Meanwhile, according to Bast in Hardiyani, the way to control angry emotions when being in unpleasant situation are relaxation, cognitive restructuring and better communication.

\section{CONCLUSION}

Tuberculosis patients have a tendency to experience emotional disturbance due to the illness. Deep breathing relaxation techniques conducted over three weeks is effective to control emotions of patients with tuberculosis. 


\section{ACKNOWLDGMENTS}

The authors would like to thank to the Head and staffs of the Society Pulmonary Health (BKPM)

Magelang who has given permission to conduct research, and also to all of research respondents.

\section{REFERENCES}

[1] WHO, "Global Tuberculosis Report [Internet]," vol. 1, 2015. Available from: https://www.health-e.org.za/wpcontent/uploads/2015/10/Global-TB-Report-2015-FINAL-2.pdf.

[2] X. B. Paulo and P. Bruno, "Emotional distress in Angolan patients with several types of tuberculosis," Afr Health Sci., vol/issue: 15(2), pp. 2-5, 2015.

[3] Janowski K., Kurpas D., Kusz J., Mroczek B., Jedynak T., "Emotional control, styles of coping with stress and acceptance of illness among patients suffering from chronic somatic diseases," Stress Heal, vol/issue: 30(1), pp. 34-42, 2014. Available from: http://web.b.ebscohost.com/ehost/pdfviewer/pdfviewer?sid=71430802-36c5-402a8d4d-6753e2729f56@sessionmgr102\&vid=1\&hid=106.

[4] K. Chalco, et al., "Nurses as providers of emotional support to patients with MDR-TB," pp. 253-61, 2006.

[5] M N. J., Porkodi A., Akila P., "Psycho-Physiological Parameters Among Patients," J Sci, vol/issue: 4(1), pp. 23-6, 2014. Available from: http://www.journalofscience.net/File_Folder/23-26.pdf.

[6] Dahlan M. S., "Statistik Untuk Kedokteran dan Kesehatan," Jakarta, Salemba Medika, 2013.

[7] Yilmaz S. G., Arslan S., "Effects of Progressive Relaxation Exercises on Anxiety and Comfort of Turkish Breast Cancer Patients Receiving Chemotherapy," Asian Pacific J Cancer Prev, vol. 16, pp. 217-20, 2015. Available from:https://www.researchgate.net/publication/271709071_Effects_of_Progressive_Relaxation_Exercises_on_Anxi ety_and_Comfort_of_Turkish_Breast_Cancer_Patients_Receiving_Chemotherapy.

[8] Lin M., Hsieh Y., Hsu Y., Fetzer S., Hsu M., "Randomised controlled trial of the effect of music therapy and verbal relaxation on chemotherapy-induced anxiety," $J$ Sci, issue 8, pp. 988-99, 2011. Available from: http://www.ncbi.nlm.nih.gov/pubmed/21385249.

[9] Sepasi N., Qasemi A. A., Narimani M., "A comparison of efficacy of two training techniques of self- management and relax- ation on the aspects of quality of life in wom- en with cancer," vol. 6, pp. 18-28, 2014. Available from: http://bccr.tums.ac.ir/index.php/bccrj/article/view/88.

[10] Sobur A., "Psykologi Umum dalam lintasan sejarah," Bandung, Pustaka Setia, 2013.

[11] Martin L. R., Williams S. L., Haskard K. B., Dimatteo M. R., "The challenge of patient adherence," Ther Clin Risk Manag, vol/issue: 1(3), pp. 189-99, 2005. Available from: http://www.pubmedcentral.nih.gov/articlerender.fcgi?artid=1661624\&tool=pmcentrez\&rendertype=abstract

[12] D. Coon, J. O. Mitterer, "Psychology a Journey," USA, 2010.

[13] Nashiro K., Sakaki M., Mather M., "Age differences in brain activity during emotion processing: Reflections of age-related decline or increased emotion regulation?," Gerontology, vol/issue: 58(2), pp. 156-63, 2012. 